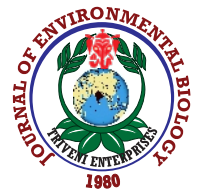

\title{
Partial purification and characterization of fatty acid esterase from pearl millet
}

\author{
S. Bajaj', L.K. Chugh ${ }^{2}$, P. Goyal ${ }^{1 *}$ and A. Kumar ${ }^{2}$ \\ 'Department of Biochemistry, CCS Haryana Agricultural University, Hisar-125004, India \\ ${ }^{2}$ Pearl Millet Quality Lab, Department of Genetics and Plant Breeding, CCS HaryanaAgricultural University, Hisar- 125 004, India \\ *Corresponding Author Email : goyalpreetigoyal@gmail.com
}

\section{Abstract}

Aim: The present study aimed to identify a negative modulator of lipolytic enzyme fatty acid esterase (FAE) for exploring possibilities of increasing shelf life of pearl millet flour through arresting in-situ hydrolysis of lipids.

Methodology: FAE was partially purified from flour of pearl millet hybrid $\mathrm{HHB} 234$ by $\left(\mathrm{NH}_{4}\right)_{2} \mathrm{SO}_{4}$ fractionation (30-60\% saturation) and gel filtration chromatography using Sephadex G-75. The enzyme was characterized for physico-chemical properties viz., molecular mass, optimum $\mathrm{pH}$, optimum temperature and thermal stability and kinetic properties viz., $\mathrm{K}_{\mathrm{m}}$ value and effect of modulators.

Results: Crude extract contained 1008 units of activity and $421 \mathrm{mg}$ proteins resulting in to specific activity of 2.4 units $\mathrm{mg}^{-1}$ protein. The enzyme was purified 10.7 fold with a recovery of $21.52 \%$ and specific activity of 25.7 units $\mathrm{mg}^{-1}$ protein by ammonium sulphate fractionation followed by gel filtration. The molecular weight of purified enzyme preparation was $60 \mathrm{kDa}$, as determined by gel filtration through Sephadex G-75. The enzyme exhibited maximum activity at $\mathrm{pH} 8.2$ and $45^{\circ} \mathrm{C}$. The enzyme was stable up to $60^{\circ} \mathrm{C}$ for $20 \mathrm{~min}$ and showed $K_{m}$ value of $0.65 \mu \mathrm{M}$ for $p-N P B$. At $10 \mathrm{mM}$

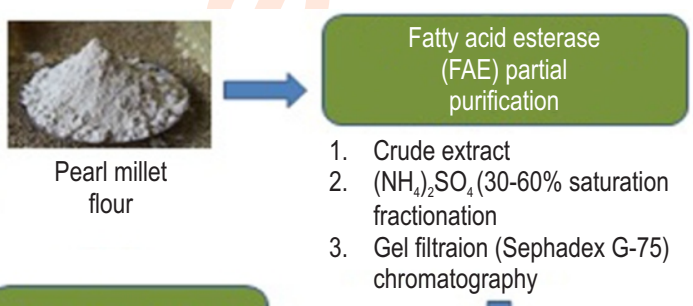

Physico-chemical characters (FAE)

$\checkmark$ Molecular Wt. : $60 \mathrm{kDa}$ $\checkmark$ Optimum pH: 8.2

$\checkmark$ Optimum temp.: $45^{\circ} \mathrm{C}$ Thermostability: $60^{\circ} \mathrm{C} .20 \mathrm{Min}$
Kinetic characters (FAE) concentration, $\mathrm{Mg}^{2+}$ and $\mathrm{Zn}^{2+}$ altered the activity positively by $54 \%$ and negatively by $42 \%$ whereas EDTA, DTT, PMSF, ascorbic acid inhibited the activity by $75,68,50$ and $48 \%$, respectively.

Interpretation: Partially purified lipolytic enzyme FAE from pearl millet flour was strongly inhibited by ascorbic acid. This novel information might be useful in developing processing technologies for improving shelf life of flour.

Key words: Characterization, Fatty acid esterase, Pearl millet, Purification, Shelf life

How to cite : Bajaj, S., L.K. Chugh, P. Goyal and A. Kumar: Partial purification and characterization of fatty acid esterase (FAE) from pearl millet. J. Environ. Biol., 42, 144-153 (2021). 


\section{Introduction}

Food security has always been a key priority due to increasing demand for food with ever increasing population. Pearl millet [Pennisetum glaucum (L.) R. Br.] is an important coarse grain cereal and forage crop of the arid and semi-arid tropics of the Indian subcontinent and several African regions. It is a central component of the food and fodder security of the rural poor residing in these areas. Nutritional profile of pearl millet is better than many other cereals. Pearl millet is the cheapest source of energy, protein, Fe and Zn among all cereals and pulses (Rai et al. 2013). Its proteins are gluten free, thus safe to consume by celiac patients (Sarita and Singh, 2016). Antioxidant activity of pearl millet hybrids and varieties is higher than that of fine cereals (Berwal et al., 2018). Dietary fibre content in pearl millet has been reported to vary by $10-11 \%$ (Iswarya and Narayanan, 2017). Pearl millet is also a good source of polyunsaturated fatty acid- rich storage lipids (Lai and Varriano-Marston, 1980a), which ranges from 4.1 to $7.5 \%$ (Goyal et al., 2017). Despite being nutritionally rich, its potential use in food industries has remained low because of short shelf life of flour owing to rapid development of rancidity.

High lipids content is one of the important factors responsible for the development of rancidity (Goyal et al., 2017). Development of hydrolytic rancidity has been strongly correlated with high activities of lipolytic enzymes esterase (Goffman and Bergman, 2003) and lipase (Rose and Pike, 2006). In-vitro and insitu activities of fatty acid esterase (FAE) and in-situ lipase of pearl millet are strongly correlated (Bajaj et al., 2016). Strong correlation between activities of FAE and lipase indicates possibilities of presence of both on a single protein has been found in wheat (Fadıloglu and Soylemez, 1996). Lipolytic activities in pearl millet are concentrated in the germ, pericarp, aleurone and subaleurone layers of pearl millet (Lai and Varriano-Marston, 1980b). Attempts through developing processing technologies for improving shelf life of its flour invariably involve reduction in lipid content and activities of lipolytic enzymes or inactivating them. Traditionally, pearl millet is decorticated by hand pounding to reduce both. However, besides being a cumbersome process decortication at domestic level also results in loss of nutrients (Tiwari et al., 2012). Refrigeration (Varsha and Narayanan, 2017), though causes suboptimal functioning of lipolytic enzymes and prolongs shelf life but has not gained favour among the industries.

Many modern grain processing techniques, for inactivating lipolytic enzyme(s) in flour such as steaming at $97^{\circ} \mathrm{C}$ for 12 min by steam-jacketed paddle conveyer (Bookwalter et al., 1987), blanching at $98^{\circ} \mathrm{C}$ for $1 \mathrm{~min}$ (Chavan and Kachare, 1994), dry heat treatment for few hours (Kachare and Chavan, 1992), toasting at $120^{\circ} \mathrm{C}$ for $16 \mathrm{hr}$ (Nantanga et al., 2008), boiling for 15 min (Nantanga et al., 2008), microwave treatment for $80 \mathrm{sec}$ at 18\% grain moisture (Yadav et al., 2012). However, such processes have either of these inherent limitations and lack wider applicability at commercial level higher cost of operation (steamjacketed paddle conveyer), loss of certain phytonutrients (blanching), change of colour of flour or products (dry heat treatment/toasting/boiling), susceptibility of products to auto oxidation of lipids (boiling) or ineffective control of auto-oxidation of lipids (microwave treatment) which lowers the nutritional value (Randhir et al., 2008). Modulators as extrinsic factors, metal ions or organic compounds of known as well as unknown function have often been employed either to identify their role as cofactor in catalysis, identification of amino acid residues in active site, or stabilizer/de-stabilizer of intra and inter subunit interactions (Zeng et al., 2014; Jensen etal., 2016) so as to change catalysis favourably.

Negative modulation of lipids hydrolyzing or oxidizing enzymes native to grains by pre treatment of grains and/or fortification of flour with food grade additives may prove to be an effective approach for decreasing their activities in flour and thus slowing down the reactions leading to minimal production of undesirable metabolites viz., free fatty acids, hydroxyperoxides, volatile aldehydes/ketones etc. Thereby improving the shelf life of flour. However, none of such reports are available on food grade additives to suppress lipolytic enzymes in pearl millet grains/flour. In view of the foregoing discussion, the present investigation was conducted to identify negative modulator of FAE. Gaining knowledge of its physico-chemical and kinetic properties is a prerequisite for identifying modulator(s) of enzyme activity which necessitates purification of $\mathrm{FAE}$.

\section{Materials and Methods}

Grain sample and preparation of flour: Mature grains of pearl millet hybrid HHB 234 were used for the study. Flour of $0.8 \mathrm{~mm}$ particles was prepared in Cyclotec machine (Foss Analytical AB, Sweden). Flour was kept in a desiccator to bring it to room temperature before preparing of crude extract.

Purification of FAE: Throughout extraction and purification, all operations were carried out at temperature between 0 and $4^{\circ} \mathrm{C}$ maintained in a cold lab (LKB, Sweden).

Crude extract: Twenty gram of flour was hand homogenized in a pre-chilled pestle and mortar in $200 \mathrm{ml}$ of $0.1 \mathrm{M}$ phosphate buffer (pH 8.0). The homogenate filtered through four layers of cheese cloth was centrifuged at $10000 \mathrm{rpm}$ for $20 \mathrm{~min}$ in a refrigerated centrifuge at $4^{\circ} \mathrm{C}$.

$\left(\mathrm{NH}_{4}\right)_{2} \mathrm{SO}_{4}$ fractionation and dialysis: The supernatant was fractionated using ammonium sulphate $\left(\mathrm{NH}_{4}\right)_{2} \mathrm{SO}_{4}$ up to $30 \%$ saturation. For further enzyme purification, the supernatant was again fractionated with $\left(\mathrm{NH}_{4}\right)_{2} \mathrm{SO}_{4}$ raising saturation to $60 \%$ which resulted in precipitation of esterase. The precipitates were dissolved in $12.5 \mathrm{ml}$ of $0.1 \mathrm{M}$ sodium phosphate buffer ( $\mathrm{pH} 8.0$ ). The resulting solution was dialyzed using properly washed dialysis membrane (Flat width $25 \mathrm{~mm}$, molecular weight cut-off limit 14000, Sigma Aldrich, USA) against the same buffer for 24 hr. Every eight hrs, the used dialysis buffer was replaced with fresh buffer. Fifteen $\mathrm{ml}$ of $\left(\mathrm{NH}_{4}\right)_{2} \mathrm{SO}_{4}$ fraction recovered after dialysis was concentrated against solid sucrose to $3 \mathrm{ml}$ which was further used for gel filtration chromatography. 
Gel filtration chromatography: Gel filtration column was prepared as follows: Sephadex G-75 (8. $50 \mathrm{~g}$ ) (particle size 40$120 \mu$, Bed volume 12-15 ml, Pharmacia Fine Chemicals, Upasala) was suspended in $300 \mathrm{ml}$ of $0.1 \mathrm{M}$ phosphate buffer $(\mathrm{pH}$ 8.0) in a beaker and allowed to swell at room temperature for $8 \mathrm{hrs}$ with intermittent shaking. Excessive buffer was decanted from the gel suspension. The suspension was poured carefully into an LKB glass column (length $100 \mathrm{~cm} x$ diameter $1.7 \mathrm{~cm}$ ) and allowed to settle by gravity. After complete sedimentation of Sephadex in the column, the effective length of column was $67 \mathrm{~cm}$.

The void volume was calculated by passing $1.5 \mathrm{ml}$ of blue dextran solution $\left(2 \mathrm{mg} \mathrm{ml}^{-1}\right.$ ) through the column as per instructions given in the Technical Bulletin of the manufacturer (Sigma-Aldrich, USA). The concentrated $\left(\mathrm{NH}_{4}\right)_{2} \mathrm{SO}_{4}$ fraction was carefully layered over the top of the Sephadex G-75 bed pre-equilibrated with $0.1 \mathrm{M}$ phosphate buffer $(\mathrm{pH} 8.0)$. The column was subsequently eluted with same buffer. The fractions $(3 \mathrm{ml})$ were collected at a flow rate of $12 \mathrm{ml} \mathrm{hr}^{-1}$. These fractions were analyzed for protein and FAE activity. The fractions with substantial FAE activity were pooled and concentrated using solid sucrose.

Protein estimation: Protein in various fractions during elution of column was monitored by measuring the absorbance at $280 \mathrm{~nm}$ on a spectrophotometer (Thermo Scientific, USA, Model Evolution 201). Quantifying of protein in crude extract was done following the method of Bradford (1976) $\left(\mathrm{NH}_{4}\right)_{2} \mathrm{SO}_{4}$ fraction and gel filtered fractions and all measurements were made in duplicates.

FAE assay: FAE activity in crude extract and in the preparations during purification process was assayed by the method of Winkler and Stuckman (1979). The assay mixture (1 ml) contained $900 \mu \mathrm{l}$ of $1: 20$ dilution of the substrate solution $A(0.3 \%$ p-NPB prepared in isopropanol) in solution $B(0.1 \%$ Gum acacia solution prepared in double distilled water), $50 \mu \mathrm{l}$ of $0.1 \mathrm{M}$ sodium phosphate buffer $(\mathrm{pH} 8.0)$ and $50 \mu \mathrm{l}$ of enzyme preparation. The reaction was started by adding enzyme. Released $p$-nitrophenol ( $p$-NP) was immediately determined by measuring the absorbance at $410 \mathrm{~nm}$ at room temperature at an interval of $15 \mathrm{sec}$ for two and a half min. The linear portion of change in absorbance was taken into account for calculating enzyme activity. One unit of esterase activity was defined equal to 0.1 change in O.D./min. All assays were performed in duplicates.

\section{Characterization of FAE}

Molecular weight: The molecular weight of purified enzyme was estimated by gel filtration chromatography. The column was calibrated with the following standard protein markers $\left(2 \mathrm{mg} \mathrm{ml}^{-1}\right.$ each): cytochrome C (12.4 kDa), carbonic anhydrase (29.0 kDa), bovine serum albumin $(66.0 \mathrm{kDa})$, alcohol dehydrogenase (150.0 $\mathrm{kDa}$ ) and beta-amylase (200 kDa). The log molecular weight of each standard protein was plotted against elution volume and the molecular weight of purified enzyme was calculated from the calibration graph.
Optimum pH: The optimum pH value for FAE was determined by assaying enzyme activity using assay buffer of $\mathrm{pH}$ values ranging from 6.0-9.0. For maintaining $\mathrm{pH}$ range 6.0 to $8.0,0.1 \mathrm{M}$ phosphate buffer was used and for $\mathrm{pH}$ above $8.0,0.1 \mathrm{M}$ Tris $\mathrm{HCl}$ buffer was used. For determining optimum pH for activity, $100 \mu$ l of purified enzyme was preincubated with $100 \mu$ l each of appropriate buffer of different $\mathrm{pH}$ values separately for $1 \mathrm{hr}$ at $27^{\circ} \mathrm{C}$. The enzyme activity was measured as mentioned earlier.

Optimum temperature and thermal stability: The optimum temperature for the enzyme was determined by measuring the enzyme activity at temperatures ranging from 20 to $65^{\circ} \mathrm{C}$. Except for the enzymes, all constituents of the reaction mixture were maintained at appropriate temperature in a water bath before starting the reaction. Enzyme activity was then determined as outlined earlier. Thermo stability of purified enzyme was tested by measuring the residual activity after incubating $100 \mu$ of enzyme for 20 min at temperature ranging from 20 to $90^{\circ} \mathrm{C}$ in a water bath.

$\mathrm{K}_{\mathrm{m}}$ value: The activity of purified preparation was measured using p-NPB as substrate at a final concentration varying from 0.3 to 2.88 $\mu \mathrm{M}$. The $\mathrm{K}_{\mathrm{m}}$ value was determined from $X$-intercept on Line weaverBurk plot of the reciprocal data drawn on Microsoft office Excel.

Effect of modulators: The effect of monovalent ions $\mathrm{Na}^{+}$and $\mathrm{K}^{+}$, divalent ions $\mathrm{Ca}^{2+}, \mathrm{Mn}^{2+}, \mathrm{Mg}^{2+}, \mathrm{Zn}^{2+}, \mathrm{Co}^{2+}, \mathrm{Cu}^{2+}$ and trivalent ions $\mathrm{Fe}^{3+}$ and $\mathrm{Al}^{3+}$ was determined by carrying out enzyme assay at different concentrations of these metal ions $(1,5$ and $10 \mathrm{mM})$. The chloride salts of all metals were used for the experiment and the residual activity was calculated taking activity of control as $100 \%$. The activity of purified preparation was also measured in the presence of following compounds at different concentrations (1 to $10 \mathrm{mM})$ : EDTA, PMSF, $\beta$-mercaptoethanol ( $\beta-M E)$, dithiothreitol (DTT), sodium dodecyl sulfate (SDS) and ascorbic acid. The percent of inhibition was expressed as relative to the enzyme activity without inhibitor.

Statistical analysis: Standard deviations were analysed using Microsoft Office Excel 2007 software.

\section{Results and Discussion}

Purification of esterase: FAE from pearl millet flour was partially purified by $\left(\mathrm{NH}_{4}\right)_{2} \mathrm{SO}_{4}$ fractionation (30-60\% saturation) and using a two steps purification procedure. The crude extract in a total volume of $180 \mathrm{ml}$ displayed 1008 units of activity and $421 \mathrm{mg}$ protein resulting in to specific activity of 2.4 units $\mathrm{mg}^{-1}$ protein (Table 1). Specific activity increased to 6.8 units $\mathrm{mg}^{-1}$ protein in $\left(\mathrm{NH}_{4}\right)_{2} \mathrm{SO}_{4}$ fraction with a recovery of $43.15 \%$. Elution profile of the enzyme through Sephadex G-75 is depicted in (Fig. 1). FAE was eluted after the major protein peak in twelve fractions numbered as 26-37. Rest of the fractions showed enzyme activity in traces. The active fractions were pooled. Total volume of pooled fractions was $36 \mathrm{ml}$. The results presented in Table 1 showed that $50.1 \%$ of the total activity present in the $\left(\mathrm{NH}_{4}\right)_{2} \mathrm{SO}_{4}$ fraction was lost. Finally, $21.52 \%$ of the total activity present in crude extract was recovered with specific activity equivalent to 25.7 units $\mathrm{mg}$ 


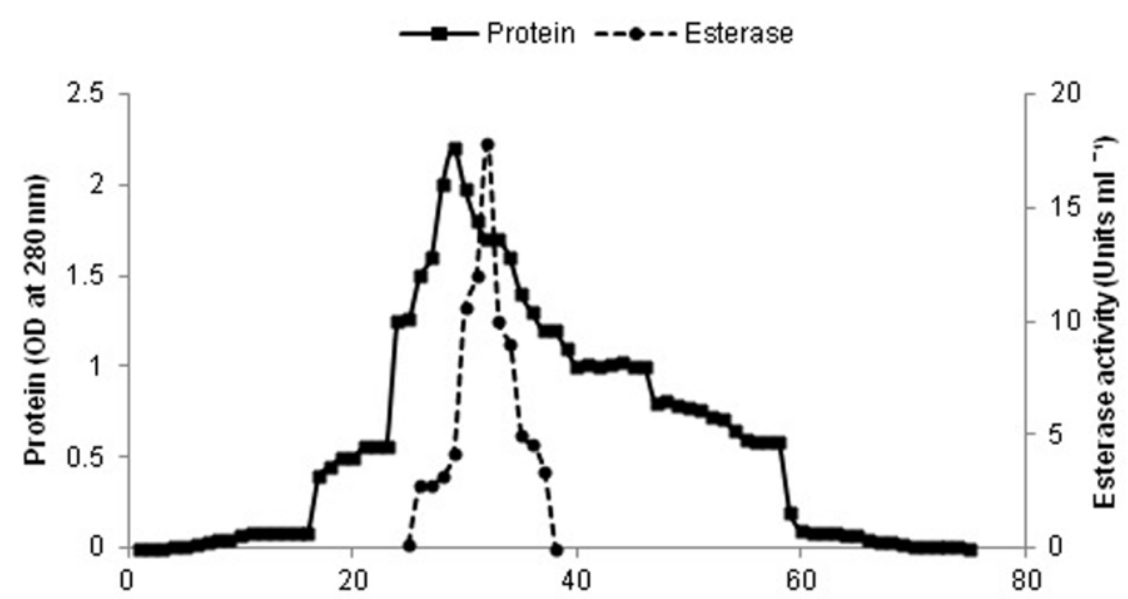

Fraction number

Fig. 1: Elution profile of fatty acid esterase on Sephdex G-75 column.

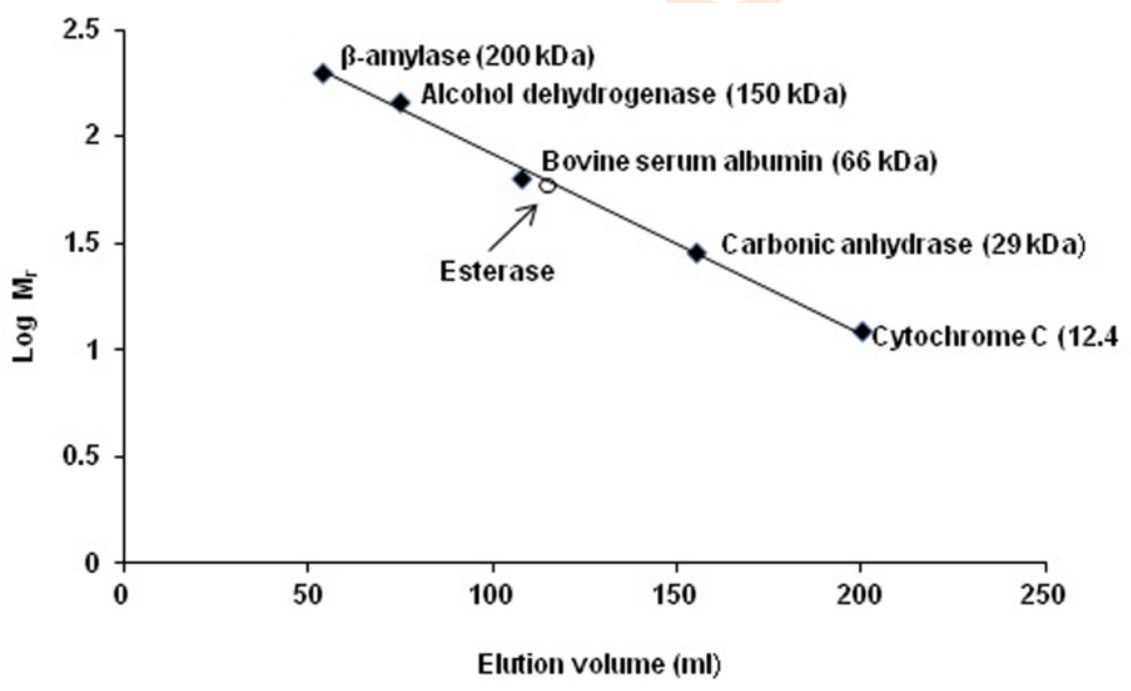

Fig. 2: Determination of molecular weight of purified fatty acid esterase by gel filtration through Sephadex G-75.

proteins ${ }^{-1}$. Thus, 10.7 fold purification was achieved. The achieved purification of FAE from pearl millet in terms of folds and specific activity was less compared to carboxyl esterase (Upadhya et al., 1985), ferulic acid esterase (Latha et al., 2007) and acetic acid esterase (Latha and Muralikrishna, 2007) purified from germinated finger millet because during the present investigation ion exchange chromatography was not carried out as has been followed by the investigators mentioned above.

Physico-chemical and kinetic properties: The purified enzyme was characterized for the following physico-chemical and kinetic properties.
Molecular weight: The molecular weight of partially purified FAE from pearl millet, determined by gel filtration was $60 \mathrm{kDa}$ (Fig. 2). The size of pearl millet FAE purified during the present investigation was closer to that of FAE I and FAE I| fractions (50$64 \mathrm{kDa}$ ) purified from yam (Dioscorea batatas) (Hou et al., 1999), carboxyl esterase of finger millet (70 kDa) (Upadhya et al., 1985) and carboxyl esterase of Tribolium castaneum (60 kDa) (Haubruge et al., 2002). Humbertson and Briggs (2002) reported that molecular weight for esterase purified from barley varied between 22 to $158 \mathrm{kDa}$ indicating the presence of multiple isoforms. According to Latha and Muralikrishna (2007) finger millet acetic acid esterase had a molecular mass of $79.4 \mathrm{kDa}$ in 


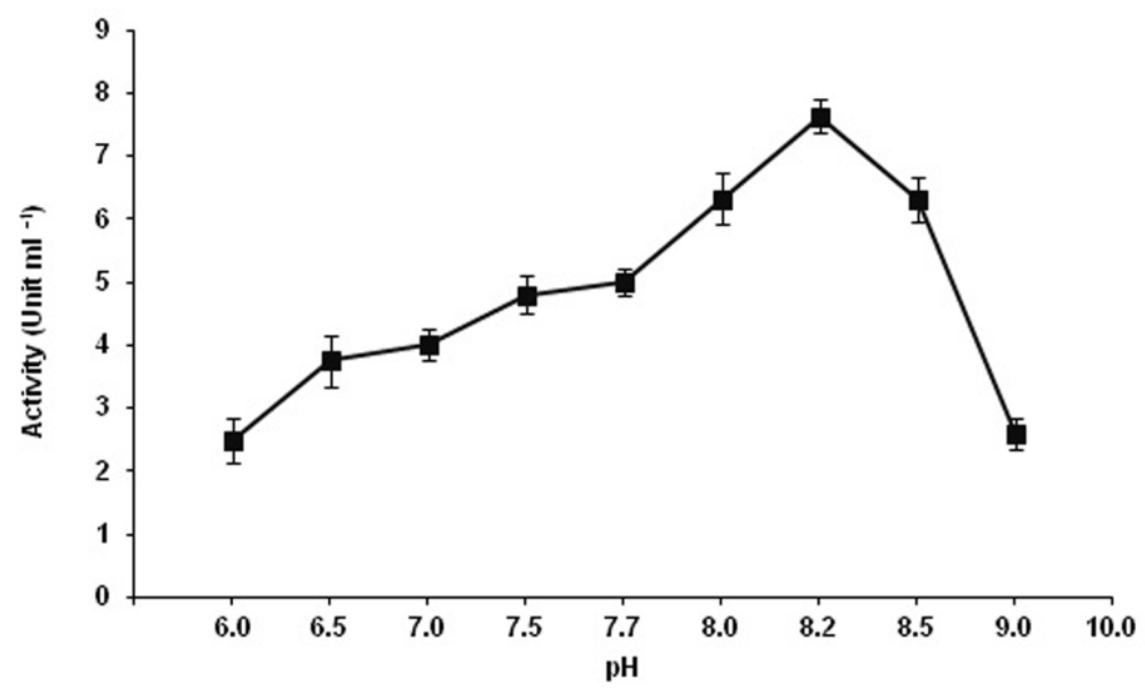

Fig. 3: Effect of pH on the activity of purified fatty acid esterase.

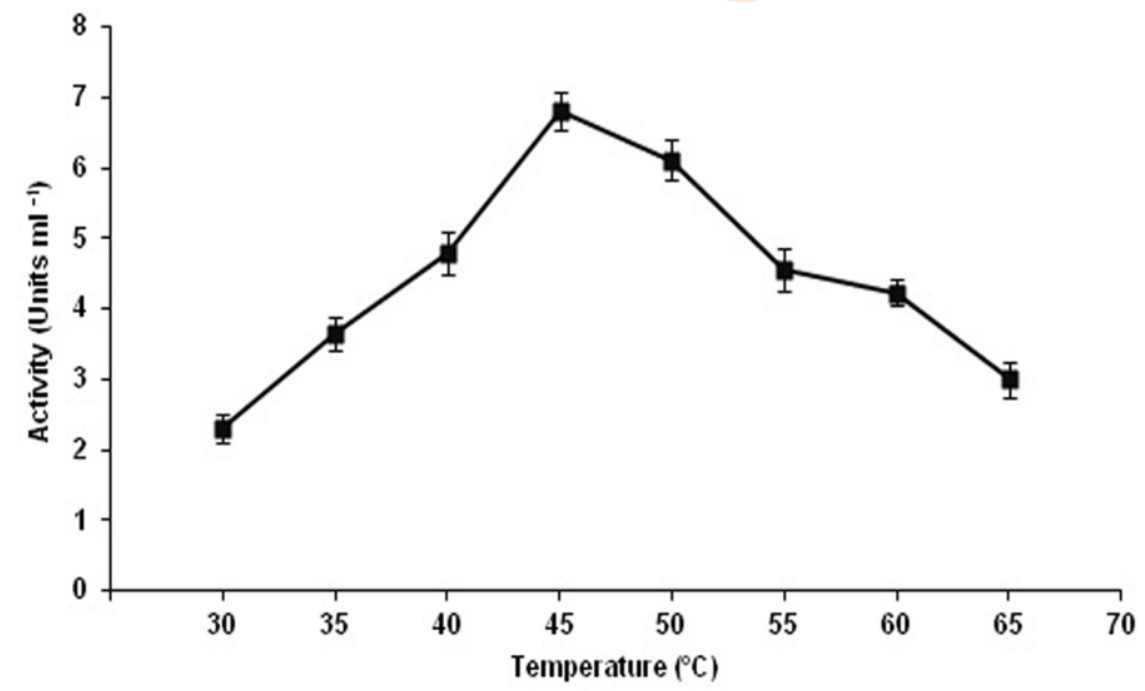

Fig. 4: Effect of temperature on the activity of purified fatty acid esterase.

native form whereas denatured enzyme was found to be a homotetramer having molecular weight of $19.7 \mathrm{kDa}$ for each subunit.

pH optimum: The effect of pH on FAE activity is depicted in (Fig. 3). Enzyme activity increased gradually from 2.48 units $\mathrm{ml}^{-1}$ at $\mathrm{pH}$ 6.0 to 6.32 units $\mathrm{ml}^{-1}$ at $\mathrm{pH}$ 8.0. Thereafter, the activity increased sharply and reached to a level of 7.64 units $\mathrm{ml}^{-1}$ at $\mathrm{pH}$ 8.2. Thereafter, the activity started decreasing rapidly with gradual increase in $\mathrm{pH}$ till 9.0. Thus optimum $\mathrm{pH}$ for obtaining maximum activity of esterase was 8.2. Staubmann et al. (1999) also reported $\mathrm{pH}$ optimum for butyrate dependent esterases isolated from Jatropha curcas seeds to be 8.0 for isoform JEA and 7.5 for the isoform JEB. Many of the plant esterases show optimum $\mathrm{pH}$ between 7 and 8 (Chandrashekharaiah et al., 2011; Bhavith et al., 2014; Kantharaju and Murthy, 2014). The pH of water extract of fresh and stored pearl millet flour varies from 6.67 to 6.25 (Goyal et al., 2015). The present investigation showed (Fig. 3) that invitro activity of $\mathrm{FAE}$ at $\mathrm{pH}$ within this (6.67 to 6.25) range was approximately $40-45 \%$ of that exhibited at $\mathrm{pH} 8.2$ (optimum $\mathrm{pH}$ ). Thus FAE is likely to be much less active in stored flour. These results corrborates with the earlier results of Bajaj et al. (2016) who demonstrated that in-situ activity of FAE in pearl millet flour is 


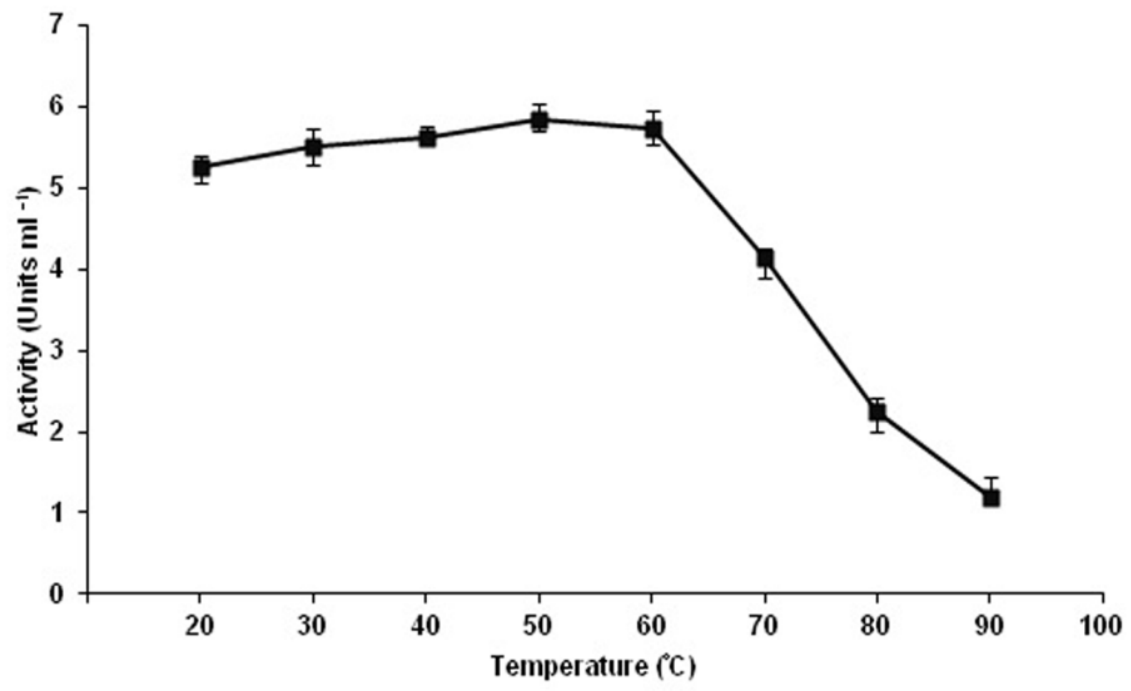

Fig. 5: Effect of temperature on the stability of purified fatty acid esterase.

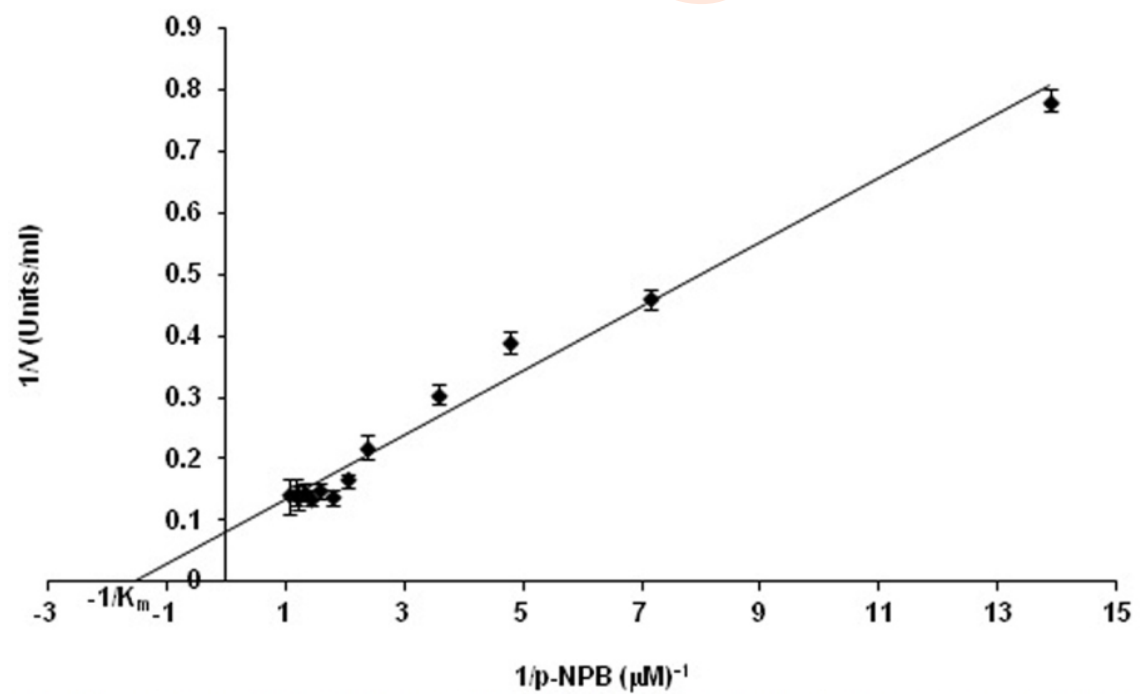

Fig. 6: Linewaever-Burk plot showing km value of purified fatty acid esterase as a function of p-NPB concentration.

about 10 folds less than the in-vitro activity. Nevertheless, in-situ hydrolysis of lipids might not get affected significantly by minor change in the $\mathrm{pH}$ of flour.

Temperature optimum and thermo stability: Profile of changes in activity in response to varying assay temperature is presented in (Fig. 4). The activity of esterase increased rapidly with increasing temperature from $30^{\circ} \mathrm{C}$ and reached to a maximum value of 6.8 units $\mathrm{ml}^{-1}$ at $45^{\circ} \mathrm{C}$. The activity started declining gradually with rise in temperature beyond $45^{\circ} \mathrm{C}$. At $60^{\circ} \mathrm{C}$ esterase lost about $39 \%$ of its activity. Thus, the purified enzyme was optimally active at $45^{\circ} \mathrm{C}$ which is higher than exhibited by yam tuber esterase (Hou et al., 1999). The optimum temperature of pearl millet FAE was lower than that $\left(50^{\circ} \mathrm{C}\right)$ of isoform JEA and nearly equal to that of isoform JEB of FAE from Jatropha curcas $L$. (Staubmann et al., 1999). Esterase from finger millet - (Latha et al., 2007; Latha and Muralikrishna, 2007), Caesalpinia mimosoides (Bhavith et al., 2014), Tamarindus indica (Kantharaju and Murthy, 2014) and soybean (Barros and Macedo (2015) have also been found optimally active at temperature near $45^{\circ} \mathrm{C}$. Enzyme normally exhibit optimum temperature ranging between 25 to $37^{\circ} \mathrm{C}$. A high optimum temperature implies that the flour 
Table 1: Summary of purification of FAE from pearl millet flour

\begin{tabular}{|c|c|c|c|c|c|c|}
\hline Fraction & $\begin{array}{l}\text { Volume } \\
\text { (ml) }\end{array}$ & $\begin{array}{l}\text { Total activity } \\
\text { (units) }^{*}\end{array}$ & $\begin{array}{l}\text { Protein } \\
\text { (mg) }\end{array}$ & $\begin{array}{l}\text { Specific activity } \\
\text { (units } \mathrm{mg}^{-1} \text { protein) }\end{array}$ & $\begin{array}{l}\text { Fold } \\
\text { purification }\end{array}$ & $\begin{array}{l}\text { Recovery } \\
(\%)\end{array}$ \\
\hline Crude extract & 180 & 1008 & 421 & 2.4 & - & 100 \\
\hline $\begin{array}{l}\left(\mathrm{NH}_{4}\right) \mathrm{SO}_{4} \text { fraction } \\
\text { (30-60\% Saturation) } \\
\text { Gel filtration }\end{array}$ & 15 & 435 & 64 & 6.8 & 2.8 & 43.15 \\
\hline (Sephadex G-75) & 36 & 217 & 8.43 & 25.7 & 10.7 & 21.52 \\
\hline
\end{tabular}

${ }^{*}$ One unit is equal to 0.1 change in O.D./min.

Table 2: Effect of various metal ions on the activity of purified FAE

\begin{tabular}{llcc}
\hline & \multicolumn{3}{c}{ Activity $\left(\%\right.$ of control) $^{*}$} \\
\cline { 2 - 4 } Metal ion & \multicolumn{3}{c}{ Concentration (mM) } \\
\cline { 2 - 4 } & 1 & $\mathbf{5}$ & 10 \\
\hline $\mathrm{Mg}^{2+}$ & $106 \pm 4$ & $122 \pm 4$ & $154 \pm 5$ \\
$\mathrm{~N}^{2+}$ & $101 \pm 3$ & $111 \pm 2$ & $141 \pm 6$ \\
$\mathrm{Al}^{3+}$ & $103 \pm 0$ & $115 \pm 0$ & $130 \pm 2$ \\
$\mathrm{Ca}^{2+}$ & $105 \pm 2$ & $107 \pm 1$ & $115 \pm 3$ \\
$\mathrm{Mn}^{2+}$ & $101 \pm 2$ & $105 \pm 0$ & $110 \pm 2$ \\
$\mathrm{Fe}^{3+}$ & $93 \pm 1$ & $88 \pm 3$ & $81 \pm 1$ \\
$\mathrm{Co}^{2+}$ & $86 \pm 2$ & $80 \pm 4$ & $77 \pm 2$ \\
$\mathrm{Cu}^{2+}$ & $89 \pm 2$ & $75 \pm 2$ & $70 \pm 2$ \\
$\mathrm{Zn}^{2+}$ & $80 \pm 2$ & $69 \pm 1$ & $58 \pm 9$ \\
\hline
\end{tabular}

Values represent mean of two determinations \pm SD; *Activity in control was 25.74 units $\mathrm{mg}$ proteins $^{-1}$ and ${ }^{*} 50$ ul extract was pre incubated with metal ions for 20 min before measuring activity at $410 \mathrm{~nm}$

stored at high temperature prevailing during summer will get deteriorated faster. In fact comparatively faster increase in fat acidity in pearl millet flour stored at higher temperature is indicative of rise in in-situ activity of lipolytic enzymes with increasing temperature (Lai and Varriano-Marston, 1980b; Kadlag et al., 1995). The enzyme purified during present investigation was thermally stable till $60^{\circ} \mathrm{C}$ and (Fig. 5) at $90^{\circ} \mathrm{C}$ the enzyme lost its activity by $81.3 \%$. Similar level of activity of ferulic acid esterase was, however, lost at $70^{\circ} \mathrm{C}$ (Latha et al., 2007). Almost identical stability behaviour has also been reported for Caesalpinia seed esterase $\left(60^{\circ} \mathrm{C}\right)$ (Bhavith et al., 2014). Hou et al. (1999) found thermo stability of FAE at temperatures below $50^{\circ} \mathrm{C}$ from yam (Dioscorea batatas) tuber. At $60^{\circ} \mathrm{C}$, about $60 \%$ of acetic acid esterase activity was decreased (Latha and Muralikrishna, 2007). Esterases of Tamarindus indica seed were even labile at temperatures below $40^{\circ} \mathrm{C}$ (Kantharaju and Murthy, 2014). Thus, pearl millet FAE was comparatively more thermostable. Rapid decline of in-vitro activities of the enzymes viz., peroxidase, lipoxygenase and polyphenol oxidase in pearl millet flour stored at $37^{\circ} \mathrm{C}$ (Goyal et al., 2015) shows in-situ instability of these enzymes. On the contrary, statistically similar levels of in-vitro as well as in-situ activities of FAE and in- situ activity of lipase in control and 10 day stored flour at the identical temperature (Bajaj et al., 2016), clearly indicates stability of these enzymes, continuous release of fatty acids making the flour rancid. Stability of purified pearl millet FAE till $60^{\circ} \mathrm{C}$ might be the result of architecture of the enzyme which needs further investigations.

$\mathbf{K}_{\mathrm{m}}$ value: Esterases comprise a diverse group of hydrolases and many of them show activity with wide range of substrates like phenyl acetate, naphthyl acetate, naphthyl propionate, pnitrophenyl butyrate (p-NPB), nitrophenyl ferulate, naphthyl myristate, etc. (Latha and Muralikrishna, 2007; Xin and Hui-Ying, 2013; Jensen et al., 2016) During the present investigation only one substrate i.e., p-NPB was used. Pearl millet FAE followed typical Michaelis-Menten kinetics with $\mathrm{K}_{\mathrm{m}}$ value of $0.65 \mu \mathrm{M}$ for $\mathrm{p}$ nitrophenyl butyrate (Fig. 6). Using identical substrate Staubmann et al. (1999) reported $\mathrm{K}_{\mathrm{m}}$ value of $0.02 \mathrm{mM}$ and 0.07 $\mathrm{mM}$ of two isoform of the enzyme from Jatropha curcas $L$. seeds. $\mathrm{K}_{\mathrm{m}}$ value equivalent to $0.11 \mathrm{mM}$ has been reported for Caesalpinia mimosoides esterase using 1-naphthyl acetate as substrate. Jensen et al. (2016) found $K_{m}$ value of $1.07 \mathrm{mM} \mathrm{p}$-NPB for carboxyl esterase from $P$ seudoalteromonas arctica. Finger millet ferulic acid esterase and acetic acid esterase showed $\mathrm{K}_{\mathrm{m}}$ value 0.053 and $0.40 \mu \mathrm{M}$ for their respective substrates (Latha and 
Table 3: Effect of chemical compounds on the activity of purified FAE

\begin{tabular}{llcl}
\hline \multirow{2}{*}{ Inhibitors } & \multicolumn{3}{c}{ Activity (\% inhibition) } \\
\cline { 2 - 4 } & \multicolumn{3}{c}{ Concentration (mM) } \\
\cline { 2 - 4 } & $\mathbf{1}$ & $\mathbf{5}$ & $\mathbf{1 0}$ \\
\hline EDTA & $28 \pm 2$ & $51 \pm 3$ & $75 \pm 4$ \\
PMSF & $21 \pm 1$ & $34 \pm 3$ & $50 \pm 0$ \\
SDS & $18 \pm 1$ & $30 \pm 2$ & $34 \pm 2$ \\
B-ME & $15 \pm 1$ & $18 \pm 0$ & $22 \pm 1$ \\
DTT & $33 \pm 2$ & $59 \pm 3$ & $68 \pm 3$ \\
Ascorbic acid & $26 \pm 2$ & $40 \pm 1$ & $48 \pm 0$ \\
\hline
\end{tabular}

Values represent mean of two determinations \pm SD; *Activity in control was 25.74 units mg protein ${ }^{-1}$ and ${ }^{*} 50$ ul extract was pre incubated with inhibitors for $20 \mathrm{~min}$ before measuring activity at $410 \mathrm{~nm}$

Muralikrishna, 2007; Latha et al., 2007). Yet higher $\mathrm{K}_{\mathrm{m}}$ value of $3.62 \mathrm{mM}$ p-nitrophenyl ferulate for feruloyl esterase from Aspergillus usamii has also been reported by Yin et al. (2015). Wide variation in the $\mathrm{K}_{\mathrm{m}}$ value of esterases is related to diversity of sources, degree of purity of enzyme preparation, methods and type of substrates used. $K_{m}$ values in $\mu \mathrm{M}$ range for $p-N P B$ for pearl millet FAE point out towards high affinity for substrate might be partly responsible for rapid hydrolysis of lipids in stored pearl millet flour.

Effect of modulators: Data presented in Table 2 showed that activity of purified esterase was stimulated by $\mathrm{Mg}^{2+} \mathrm{Na}^{+}, \mathrm{Al}^{3+}, \mathrm{Ca}^{2+}$, and $\mathrm{Mn}^{2+}$ in the decreasing order of their influence whereas $\mathrm{Fe}^{3+}$, $\mathrm{Co}^{2+}, \mathrm{Cu}^{2+}$ and $\mathrm{Zn}^{2+}$ inhibited with increasing deleterious order. Irrespective of stimulatory or inhibitory effect of these metal ions, the activity increasingly affected with changing concentration from 1 to $10 \mathrm{mM}$. For example, the presence of $\mathrm{Mg}^{2+}, \mathrm{Na}^{+}, \mathrm{Al}^{3+}, \mathrm{Ca}^{2+}$ and $\mathrm{Mn}^{2+}$ in the assay mixture at $10 \mathrm{mM}$ increased the activity by $54,41,30,15$ and $10 \%$, respectively. Similarly at $10 \mathrm{mM}$ concentration, $\mathrm{Fe}^{3+}, \mathrm{Co}^{2+}, \mathrm{Cu}^{2+}$ and $\mathrm{Zn}^{2+}$ inhibited the activity by 19 , 23, 30 and $42 \%$, respectively. Thus, $\mathrm{Mg}^{2+}$ and $\mathrm{Zn}^{2+}$ which altered the activity positively by $54 \%$ and negatively by $42 \%$, were the most potent stimulator and inhibitor of the purified pearl millet FAE. The effect of these metals on the activity of purified esterases from different plant or microbial sources reported in literature is not equivocal (Staubmann et al., 1999; Latha and Muralikrishna, 2007; Latha et al., 2007; Barros and Macedo, 2015; Hu et al., 2018). Data on inhibition of esterase by different compounds is presented in Table 3. FAE activity was highly inhibited by the metal chelator, EDTA. For investigating the essentiality for metal ion cofactors, the effect of EDTA was examined. At the highest concentration of EDTA (10 mM), $75 \%$ inhibitory effect was visible on the activity, while at $1 \mathrm{mM}$ EDTA, the activity decreased to $28 \%$ of the control.

A strong inhibitory effect at lowest concentration $1 \mathrm{mM}$ otherwise observed at $10 \mathrm{mM}$ would have indicated absolute requirement of metal ions as cofactor for the activity. The observed stimulatory and inhibitory effects of metal ions showed stability of the enzyme. The modest inhibitory effect encountered with EDTA suggests that certain metals can have a stabilising effect on the structure of the enzymes. $\mathrm{Al}^{3+}$ and $\mathrm{Co}^{2+}$ are not constituents of pearl millet. Abundance of major nutrients $\mathrm{Mg}^{2+}$ and $\mathrm{Na}^{+}$(both stimulators of FAE) and deficiency in micronutrient $\mathrm{Zn}^{2+}$ (strongest inhibitor of FAE) in pearl millet might be favourable for stability of FAE in flour. Inhibition of enzyme by phenylmethylsulfonyl fluoride is in accordance with the earlier reports on negative impact of this compound on extracellular esterase from Salimicrobium sp. LY19 (Xin and Hui-Ying, 2013). Inhibition of esterase enzymes by PMSF at all concentrations suggests that serine residues are essential for its catalytic function. The disulphide bond reducing agents betamercaptoethanol ( $\beta-M E)$ and dithiothreitol (DTT) showed concentration dependent inhibitory effect on the enzyme activity though $\beta-\mathrm{ME}$ was comparatively less effective. At $5 \mathrm{mM}$ concentration, $\beta-M E$ and DTT inhibited the activity by 18 and 59 $\%$, respectively (Table 3 ). Many of the esterases contain multiple cysteine residues which are capable of forming disulphide bridges (Jensen et al., 2016). The effect of reducing agent DTT on the activity of this enzyme may be a consequence of destabilisation of disulphide bonds, which indicates that cysteine residues may be necessary for the activity and/or stability of enzyme by forming disulphide bridges. Studies of Yin et al. (2015) have shown that disulfide bridges contribute significantly to the thermostability of feruloyl esterase.

The observed thermostability (motioned above) of pearl millet FAE might be the result of disulphide bridges. Sodium dodecyl sulphate (SDS), an anionic surfactant, which can destroy the non-covalent bonds between enzyme molecules and change the conformation of enzyme also, inhibited FAE activity significantly in a concentration dependent manner (Table 3). Inhibition of enzyme activity by SDS is in accordance with the observed negative impact of this compound on esterase from Stenotrophomonas maltophilia (Gao et al., 2019). Ascorbic acid also showed detrimental effect on the purified pearl millet esterase (Table 3). At 5 and $10 \mathrm{mM}$, it caused 42 and $48 \%$ reduction in its activity. The ability of ascorbic acid to inhibit the enzyme appears due to lowering of $\mathrm{pH}$ of the reaction medium. Final $\mathrm{pH}$ of the reaction mixture 
adding 3 and $10 \mathrm{mM}$ ascorbic acid was 5.32 and 4.09. The observed significantly lower levels of activity recorded at $\mathrm{pH}$ below the optimum (Fig. 3) supports this hypothesis.

Among the negative modulators identified, ascorbic acid is a known antioxidant and is used frequently as a safe food additive. Its use in developing processing technologies such as steeping of grains in ascorbic acid or fortification of flour with ascorbic acid for slowing down in-situ hydrolysis of lipids through inactivating lipolytic activities for improving shelf life of flour might be explored. Simultaneous inhibition of pearl millet lipoxygenase by ascorbic acid (Sharma and Chugh 2017) might also delay oxidation of unsaturated fatty acids.

\section{Acknowledgment}

Financial assistance in the form of merit scholarship awarded to Sonali Bajaj by Chaudhary Charan Singh Haryana Agricultural University, Hisar (India) is deeply acknowledged.

\section{Add-on Information}

Authors' contribution: S. Bajaj: Execution of the experiment; L.K. Chugh: Planning of the experiment, Interpretation of data and Discussion of results; P. Goyal: Writing of Manuscript; A. Kumar: Statisitical analysis and Review of Manuscript

Research content: The research contents is original and has not been published elsewhere

Ethical approval: NotApplicable.

Conflict of interest: The author declares that there is no conflict of interest.

\section{Data from other sources: NotApplicable}

Consent to publish: All authors agree to publish the paper in Journal of Environmental Biology.

\section{References}

Bajaj, S., L.K. Chugh, P. Goyal, R. Kumar and D. Vart: In-vitro and in-situ activities of lipolytic enzymes and hydrolysis of lipids in flour of pearl millet designated B-lines. In: Proceedings. International. Conference. on Innovative Research in Agriculture, Food Science, Forestry, Horticulture, Aquaculture, Animal Sciences, Biodiversity, Ecological Sciences and Climate Change (AFHABEC-2016), JNU, New Delhi, p. 73 (2016).

Barros, M. and G.A. Macedo: Biochemical characterization of purified esterase from soybean (Glycine max L.). J. American Oil Chem. Soc., 92, 37-45(2015).

Berwal, M.K., P. Goyal and L.K. Chugh: Exploitation of pearl millet germplasm for identification of low grain phytate containing parental lines. J. Agric. Ecol., 6, 39-46 (2018).

Bhavith, K.P., M.N. Swamy, N.R. Swamy and K.S. Chandra shekharaiah: Purification and characterization of esterase from the seeds of Caesalpinia mimosoides. J. Exp. Biol. Agric. Sci., 2, 635-641 (2014)
Bookwalter, G.N., S.A. Lyle and K. Warner: Millet processing for improved stability and nutritional quality without functionality changes. J. Food Sci., 52, 399-402 (1987).

Bradford, M.M.: A rapid and sensitive method for the quantitation of microgram quantities of protein utilizing the principle of protein-dye binding. Anal. Biochem., 72, 248-254 (1976).

Chandra shekharaiah, K.S., N.S. Swamy and K.R. Murthy: Carboxylesterases from the seeds of an underutilized legume, Mucuna pruriens: Isolation, purification and characterization. Phytochemistry, 72, 2267-2277 (2011).

Chavan, J.K. and D.P. Kachare: Effect of seed treatment on lipolytic deterioration of pearl millet flour during storage. J. Food Sci. Technol., 31, 81-82 (1994).

Fadıloglu, S. and Z. Soylemez: Preliminary kinetic studies on the esteratic and lipolytic components of a commercial wheat germ lipase. J. Agric. Food Chem., 44, 3015-3017 (1996).

Gao, X., X. Mao, P. Lu, F. Secundo, C. Xue and J. Sun: Cloning, expression and characterization of a novel thermostable and alkaline-stable esterase from Stenotrophomonas maltophilia OUC_Est10 catalytically active in organic solvents. Catalysts, $\mathbf{9}$, 401-412 (2019).

Goffman, F.D. and C. Bergman: Relationship between hydrolytic rancidity, oil concentration and esterase activity in rice bran. Cereal Chem., 80, 689-692 (2003).

Goyal, P., L.K. Chugh and S. Bajaj: Improving shelf life of pearl millet flour through conventional plant breeding approach. In Proceedings of the India International Science Festival-Young Scientists Meet. Department of Science and Technology, Government of India, Paper Code: Innov 61 (2015).

Goyal, P., L.K. Chugh and M.K. Berwal: Storage effects on flour quality of commonly consumed cereals. J. Appl. Nat. Sci., 9, 551-555 (2017).

Haubruge, E., M. Amichot, A. Cuany, J. Berge and L. Arnaud: Purification and characterization of carboxyleaterse involved in malathionspecific resistance from Tribolium castaneum. Insect Biochem. Mol. Bio., 32, 1181-1190 (2002).

Hou, W., H. Chen, C. Chang and Y. Lin: Purification and properties of fatty acid esterases from yam (Dioscorea batatas) tuber. Bot. Bull. Acad. Sin. Taipei., 40, 305-310 (1999).

Humberston, F.J. and D.E. Briggs: Partial purification of ferulic acid esterase from malted barley. J. Inst. Brew., 108, 439-443 (2002).

$\mathrm{Hu}$, J., W. Cai, C. Wang, X. Du, J. Lin and J. Cai: Purification and characterization of alkaline lipase production by Pseudomonas aeruginosa HFE733 and application for biodegradation in food wastewater treatment. Biotech. Biotech. Equip., 32, 583-590 (2018).

Iswarya, A.L. and A. Narayanan: Effect of germination on biofortified pearl millet cultivars' nutrient content. Int. J. Innov. Res. Edu. Sci., 3, 2349-5219 (2017).

Jensen, M-B. V., L.E. Horsfall, C. Wardrope, P.D. Togneri, J. Ma-Wright and S.J. Rosser: Characterisation of a new family of carboxyl esterases with an OsmC domain. PLoS ONE, 11, e0166128 (2016).

Kachare, D.P. and J.K. Chavan: Effects of seeds treatment on the changes in fat acidity of pearl millet meal during storage. Ind. J. Agri. Biochem., 5, 15-20 (1992).

Kadlag, R.V., J.K. Chavan and D.P. Kachare: Effects of seed treatments and storage on the changes in lipids of pearl millet meal. Plant Food Hum. Nutr., 47, 279-285 (1995).

Kantharaju, S. and K.R.S. Murthy: Characterization of esterase of Tamarindus indica seeds. J. Biosci. Med., 2, 54-62 (2014).

Lai, C.C. and E. Varriano-Marston: Lipid content and fatty acid composition of free and bound lipids in pearl millet. Cereal Chem., 57, 271-274 (1980a). 
Lai, C.C. and E. Varriano-Marston: Changes in pearl millet meal during storage. Cereal Chem., 57, 275-277 (1980b).

Latha, G.M. and G. Muralikrishna: Purification and partial characterization of acetic acid esterase from malted finger millet (Eleusine coracana, Indaf-15). J. Agric. Food Chem., 55, 895- 902 (2007).

Latha, G.M., P. Srinivas and G. Muralikrishna: Purification and characterization of ferulic acid esterase from malted finger millet (Eleusine coracana, Indaf-15). J. Agric. Food Chem., 55, 97049712 (2007).

Nantanga, K.M.K., K. Seetharaman, H.L. de Kock and R.N.J. Taylor: Thermal treatments to partially pre-cook and improve the shelf life of whole pearl millet flour. J. Sci. FoodAgric., 88, 1892-1899 (2008).

Rai, K.N., G. Velu, R. Bhattacharjee, V.N. Kulkarni, V. Muralidharan, T. Longvah and T.S. Raveendran: Gene action for grain zinc content in pearl millet. Crop Improv., 35, 186-191 (2013).

Randhir, R., Y.I. Kwon and K. Shetty: Effect of thermal processing on phenolics, antioxidant activity and health-relevant functionality of select grain sprouts and seedlings. Innov. Food Sci. Emerg. Technol., 9, 355-364 (2008).

Rose, J.D. and O.A. Pike: A Simple method to measure lipase activity in wheat and wheat bran as an estimation of storage quality. J. Am. Oil Chem. Soc., 83, 415-419 (2006).

Sarita and E. Singh: Potential of Millets: Nutrients composition and health benefits. J. Sci. Innov. Res., 5, 46-50 (2016).

Sharma, B. and L.K. Chugh: Two isoforms of lipoxygenase from mature grains of pearl millet [Pennisetum glaucum (L.) R. Br.]: Purification and physico-chemico-kinetic characterization. J. Food Sci. Tech., 54, 1577-1584 (2017).

Staubmann, R., I. Ncube, G.M. Gubitz, W. Steiner and J. S. Read: Esterase and lipase activity in Jatropha curcas $L$. seeds. J. Biotechnol., 75, 117-126 (1999).

Tiwari, A., S.K. Jha, R.K. Pal, S. Sethi and L. Krishan: Effects of premilling treatments on storage stability of pearl millet flour. J. Fd. Proc. Pres., 38, 1215-1223 (2012).

Upadhya, G.A., L. Govardhan and P.S. Veerabhadrappa: Purification and properties of a carboxylesterase from germinated finger millet (Eleusine coracana Gaertn). J. Biosci., 7, 289-301 (1985).

Varsha, R. and A. Narayanan: Storage stability of biofortified pearl millet flour. Int. J. Agri. Innov. Res., 5, 709-713 (2017).

Winkler, U.K. and M. Stuckmann: Glycogen, hyaluronate and some other polysaccharides greatly enhance the formation of exolipase by Serratia marcescens. J. Bacteriol., 138, 663-670 (1979).

Xin, L. and Y.H. Ying: Purification and characterization of an extracellular esterase with organic solvent tolerance from a halotolerant isolate, Salimicrobium sp. LY19. BMC Biotech., 13, 1-8 (2013).

Yadav, D.N., T. Anand, J. Kaur and A.K. Singh: Improved storage stability of pearl millet flour through microwave treatment. Agric. Res., 1, 399-404 (2012).

Yin, X., D. Hu, J.F. Li, Y. He, T.D. Zhu and M.C. Wu: Contribution of disulfide bridges to the thermostability of a type A feruloyl esterase from Aspergillus usamii. PLoS ONE, 10, e0126864 (2015).

Zeng, J., X. Gao, Z. Dai, B. Tang and X.F. Tang: Effects of metal ions on stability and activity of hyperthermophilic pyrolysin and further stabilization of this enzyme by modification of a $\mathrm{Ca}^{2+}$-binding site. App. Environ. Microbiol., 9, 2763-2772 (2014). 